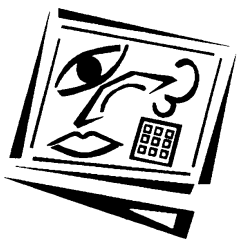

\title{
Learning strategies and motivational factors predicting information literacy self-efficacy of e-learners
}

\author{
Ebru Kiliç-Çakmak \\ Gazi University
}

\begin{abstract}
Rapid increase in information sources in different formats, developments in technology and need for lifelong learning have drawn increased attention to needs for information literacy. Although information literacy is significant for students of all educational levels, it has become even more significant for e-learners. Therefore, this study explores learning strategies and motivational factors predicting information literacy self-efficacy of e-learning students. This study was carried out with 119 elearners using the Information Literacy Self-efficacy Scale and the Motivated Strategies for Learning Questionnaire. Results indicate that metacognitive, effort management, elaboration and critical thinking strategies, as well as control belief, predict different dimensions of information literacy self-efficacy.
\end{abstract}

\section{Introduction}

The United States Distance Learning Association defines distance learning as "a combination of technologies that facilitate teaching and learning among persons not physically present in the same location" and "the application of information technology (and infrastructure) to educational and student-related activities linking teachers and students in differing places" (USDLA, 2006).

E-learning is a learning environments in which students and teachers come together at certain times online, in synchronised or asynchronised activities; course content is presented with special techniques; and students, in general, perform learning duties and activities individually. E-learning environments that offer appealing education alternatives and lifelong learning opportunities provide students with stand alone, independent, and self-directed learning processes. As mentioned by Chen and Lin (2002), within e-learning environments, individual characteristics of students become even more prominent and may affect their success directly.

Learning in the 21st century is more student centred, oriented towards lifelong learning and changing in a manner to that promotes development. Considering distance learning systems, limits associated with time and space are being minimised. Learning is being transformed into a structure that is more self directed, nests with working and personal life; is based on resources, and requires continuing access to learning resources. Moreover, it shifts from "know what" to "knowing how, how to learn, how to secure information, use it, and how to relate to a changing society" (Thomas, 1995:54; Sacchanand, 2002). Therefore, as stated by Sacchanand (2002), elearners should be self directed, have a background of independent studying and having control over their learning. To be successful with e-learning processes, students should learn how to learn; be an information literate person; use appropriate learning 
strategies and keep their motivation high in learning processes. The report published by the American Library Association [ALA] (2000) highlights the significance of information literacy for distance learning applications, where students and teachers are not present simultaneously in the same environment, and information resources are presented via distributed learning technologies.

\section{Information literacy and e-learning}

Information literacy is a necessary skill for individuals to recognise when information is needed and have the ability to locate, evaluate, and use effectively the needed information. Importance of information literacy is increasing rapidly in parallel with current needs due to technological changes, and increase and multiplication in information sources. Since information sources have become more complex, people in their academic studies, in the workplace, and in their personal lives are confronted with various and abundant information. Information can be accessed through libraries, community resources, special interest organisations, media, and the Internet. However, these sources are unfiltered, and the validity, reliability and factuality of them should be questioned. Moreover, information can be presented in the form of graphics and texts, and audiovisually via multimedia, which may result in people having difficulty in understanding and assessing this information. Ambiguity in the quality of information and its quantitative increase become complex for societies. Without existence of necessary abilities to use information in an effective manner, information abundance alone cannot create a better informed society (ALA, 2000).

Information literacy is the key competency that is of vital importance particularly for independent studying, self-directed learning, lifelong learning and social development. Doyle (1992) defines information literacy as "to access, evaluate, and use information from a variety of sources". Information literacy has been defined as being comprised of four interconnected components: 1) knowledge of information sources, the organisation of information, and the nature of knowing the attributes of scholarly knowledge; 2) skills in finding, evaluating, using and effectively communicating information; 3) generalisation of knowledge and skills to various applied settings with a positive disposition toward the use of new and extant information sources and information technologies; and 4) social context for the use of information, equability of access to information and the dissemination of knowledge (Senate Committee on Curricular Affairs, 2004). Information literacy is the set of literacy or competencies that an informed citizen needs in order to participate judiciously and actively in an information society. Information literacy is vital for the modern intensively information-based world, and it also provide personal, economic, social and cultural development (Pinto, 2010).

Information literacy forms the basis of lifelong learning. This is common for all disciplines, learning environments and all levels of education. It enables learners to master content and extends their investigations, become more self-directed, and assumes greater control over their own learning (ALA, 2000) and these features are the fundamental features that e-learners are required to have. An information literate individual is able to (ALA, 2000):

- Determine the extent of information needed

- Access required information effectively and efficiently

- Assess information and its sources critically

- Incorporate selected information into one's knowledge base 
- Use information effectively to accomplish a specific purpose

- Understand the economic, legal, and social issues surrounding the use of information, and access and use information ethically and legally.

Information literacy is important for enhancing success of learners as well (Lance \& Potter, 1995:126; cited in Sacchanand, 2002). Especially for individuals who prefer independent learning, it has become important not to be lost in a surfeit of information. Moreover, Lyman (1999) states that information literacy, searching and navigating and spreadsheet and presentation skills are the skills required to be possessed by especially those students who prefer independent learning within flexible learning environments (Gerbic, 2004). ALA (1989) stresses that, e-learners who are, in general, obliged to study independently, should have information literacy skills in order to determine and search the information needed, to evaluate information obtained, to decide on the accuracy of and to use the information. In brief, individuals who are information literate persons are more successful in lifelong learning processes. However, awareness with regard to the significance of information literacy should be raised among students and their self-efficacy should be improved. Rowntree (1995), on the other hand, indicates that students should have information literacy, time management and interpersonal interaction skills for achievement within e-learning environments (Rovai, 2003). Enhancing skills such as information literacy, especially digital information literacy, that are necessary for effective use of information will also encourage life-long learning skills (Candy et al., 1994; Kelly, Coburn, Hegarty, Jeffrey \& Penman, 2009).

When knowledge is rapidly outdated or changing, students will need information literacy skills in order to reach, comprehend and make use of knowledge in their disciplines of study. Therefore, in higher education, instructors should give their lectures, develop methods and arrange curricula in a manner that students acquire those skills (Feast, 2003). As access to information becomes easier and less expensive, the skills and competencies relating to the selection and efficient use of information become more crucial (Corrall, 2008).

"Information literacy is a survival skill in the information age", say Breivik \& Gee (1989, p. 12), and should help keep one from "drowning in the abundance of information" that floods our lives. It is not only important in the workplace but also in personal life. Some library professionals regard the teaching of information literacy as the teaching of conceptual foundations and organisation of information sources and systems, namely, as education in the awareness of scope and options. Breivik \& Gee (1989, p. 24) note that (the teaching of) an integrated set of skills (research strategy and evaluation) and knowledge of tools and resources are all included in it. The key objective for information literacy is critical thinking (Bodi, 1990), in other words, the ability of an individual to examine all sides of an issue and extract objectively the relevant arguments, while at the same time considering the expertise level and biases of the supporters of the different arguments, and then to logically synthesise the information to meet that individual's needs (cited in Hawes, 1994).

Being under pressure from major stakeholders such as future employers, many business schools have felt the necessity to change their curricula in order to better prepare their students with all necessary skills, including literacy skills. Curriculum develops information literacy strategies for solving problems effectively or carrying out research in any discipline (Johnson, Bartholomew \& Miller, 2006). Many higher education institutions are launching projects with an aim of enhancing student 
information literacy, since advancing student information literacy will enhance learning and support students academically. At the same time it provides the abilities needed for professional success after graduation (Maybee, 2006). Donaldson (2000) states that those students who want to be successful in their educational careers certainly need to improve their information literacy skills and research strategies. Information and communication technologies develop rapidly and the information environment becomes increasingly complex, which explain the reasons as to why educators are recognising the needs for learners to engage with the information environment as part of their formal learning processes. Information literacy also comes to the fore in the pursuit of lifelong learning, and is the key for achieving both personal empowerment and economic development (Bruce, 2004).

Learning opportunities that enhance information literacy not only utilise information and communication infrastructures, but are designed also to bring information practices, which are effective in professional, civic and personal life, into the curriculum. Such opportunities enable learners of all ages to experience the power of effective information practices. When reflection on learning to be information literate is added to the experience of information literacy, students are assisted to be aware of the opportunity to transfer the processes to everyday life, community and workplace. What is significant with information literacy education is its potential to encourage deep, rather than surface learning, and its potential to transform dependent learners into independent, self directed, lifelong learners. Models and standards such as Big6 information skills (Eisenberg \& Berkowitz, 1990), attributes of an information literate person (Doyle, 1992), Bruce's seven faces of information literacy (Bruce 1997), the information literacy standards for student learning (ALA \& AECT, 1998) and the ALA information literacy competency standards for higher education (ALA, 2000) are used for communicating the character of information literacy, for curriculum design and evaluation, for staff development, and for assessing students (Bruce, 2004). As it is stated in the case study by Kelly, Coburn, Hegart, Jeffrey \& Penman (2009), digital information literacy capability has great importance on the advance of technology. The result of the study reflects that a significant change has occurred in the overall confidence of the participant in using computer based, Internet based communication and information tools.

Pinto (2010) states that information literacy embraces both the use and the creation of information under the umbrella of critical thinking and emotion. Pinto defines knowledge construction, or in other words, three dimensions of educational activity as knowledge, skills and attitude. Pinto also adds, information literacy needs some activities, although each learner has different knowledge, skills and attitudes. Even though attitude has an important role in acquiring information literacy, it is perhaps the least studied dimension among these activities, including the role that motivational strategies may have in improving attitudes.

Up to now, research on and development of information skills instruction has focused almost exclusively on content (the research process) or learning outcomes, with little or no attention paid to presentation methods that influence student motivation. In fact, little is known about the type or number of motivators that appear to be the most effective in stimulating students' task engagement and enjoyment of the research process (Small, Zakaria \& El-Figuigui, 2004). Students can become information literate only if they proactively and independently choose to pursue the opportunities that are available to them during the process of their education. The idea of individual 
responsibility for self development and learning is powerful, and is viewed by faculty members as a strong indicator of a student benefiting from their educational experience as a whole, and not only in information literacy area (McGuiness, 2006). Therefore this study investigates the motivational and learning strategies that affect information literacy of e-learners.

\section{E-learning, learning strategies and motivation}

Although online learning procedures are designed in such a way that supports personal and interpersonal information sharing and configuration via stand alone and interactive activities; students should be individuals who are highly motivated, use different learning strategies, and possess reflective thinking and metacognitive skills.

Learning strategies are the techniques that are of great importance for e-learners and facilitate self learning. Learning strategies aim at enabling the learner to process and acquire information indelibly. Hence, learning strategies are composed of behaviors and thoughts that are expected to affect learner's selection, organisation and integration of new information to be acquired (Weinstein \& Mayer, 1986). Apart from facilitating easy and permanent learning, learning strategies increase efficiency in learning and qualify learners for more independent learning.

Motivation is the total of person's behaviors and expectations. The state of being motivated covers behaviors stemming from desires. A motivated person is the one who integrates his/her knowledge and beliefs with successful behaviors. Albeit depending on expectations, motivation also includes a person's perception of self competencies and control over efforts (Stipek, 1998).

There are a lot of studies illustrating effect of differing learning strategies and motivational factors used by students on their success (Pintrich \& De Groot, 1990; Higgins, 2000; Pokay \& Blumenfeld, 1990). Additionally, the study by Nevgi (2001) on virtual university students indicates that motivation has a positive effect on learning process and helps develop more effective learning strategies. Students' level of motivation and their use of appropriate learning strategies in appropriate situations is the key for being successful throughout their educational careers (Pintrich, Smith, Garcia \& McKeachie, 1993; Garcia \& Pintrich, 1996; Zimmerman \& Martinez-Pans, 1990; Pintrich \& De Groot, 1990).

Achieving competency of independent learning through proper learning strategies and ensuring successful configuration of information by using cognitive and metacognitive strategies as well as having energy for appropriately managing this process are especially important for e-learners. Through having learning experiences independently, the e-learners may take greater responsibility for what, when and how to study, and for overcoming the limitations of place and time (Barnard et al., 2009). Elearners need to know what type of information they need; how this information can be accessed; which sources they need to to consult; and how to determine whether the information is reliable and valid. As in traditional learning environments, in online environments the need to be a self-regulated learner has great importance (Whipp \& Chiarelli, 2004; Azevedo, 2005; Dabbagh \& Kitsantas, 2005; Hodges, 2005; Kramarski \& Mizrachi, 2006; Sharma et al., 2007; Barnard et al., 2009; Tsai, 2009). 
It is considered that designing activities which improve the motivational and learning strategies of e-learners will be more effective in improving their information literacy levels rather than simply giving lectures. Therefore, this study aims at determining learning strategies and motivational factors that predict students' information literacy self-efficacy.

\section{Method}

\section{Participants}

The research was carried out on e-learners studying at Gazi University Distance Learning Programs at June, 2008. Attempts were made to contact all students enrolled in these programs. 119 volunteered with 55.5\% studying Computer Technologies and Programming, and 44.5\% were students of Business Administration. $52.9 \%$ of students were in their first year, $47.1 \%$ of students were in their second year; $63 \%$ were females, $37 \%$ were males. $61.3 \%$ of students were 20 years or younger, $27.7 \%$ were aged $21-25$ years, and 13\% aged 26-30 years of age. With regard to types of their schools, $32.8 \%$ of students were graduates from regular high schools, $58.8 \%$ of students were graduates from vocational high school and $8.4 \%$ were graduates from other types of high schools.

According to students' replies to questions related to computer and Internet infrastructure required for accessing lessons, 95\% have a computer at home; 93.3\% have Internet access at home. Those who have neither computer nor Internet access stated that they are working and using their computers at work. Their durations of computer use are $44.5 \%$ have been using computers for 6-7 years, 30.3\% for 4-5 years, $14.3 \%$ for $3-4$ years, $8.4 \%$ for $1-2$ years and $2.5 \%$ for less than one year. Their durations of Internet use are as follows: $14.3 \%$ for $6-7$ years, $23.5 \%$ for $4-5$ years, $26.9 \%$ for $3-4$ years, $29.4 \%$ for $1-2$ years and $5.9 \%$ for less than 1 year.

\section{Data collecting tools}

Information literacy self-efficacy scale

In determining students' information literacy self-efficacy, the information literacy selfefficacy scale developed by Kurbanoglu, Akkoyunlu \& Umay (2006) was used. The scale is composed of 7 factors and 28 items. The factors of the scale are determined as "defining the need for information", "initiating the search strategy", "locating and accessing the resources" "assessing and comprehending the information", "interpreting, synthesising, and using the information", "communicating the information" and "evaluating the product and process". The scale is in the form of seven-point Likert scale scored on $7=$ almost always true, $6=$ usually true, $5=$ often true, 4 = occasionally true, $3=$ sometimes but infrequently true, $2=$ usually not true, 1 $=$ almost never true. The Cronbach Alpha internal consistency is calculated as 0.92. Some examples of the scale items are shown in Table 1.

Motivated Strategies for Learning Questionnaire

The Motivated Strategies for Learning Questionnaire (MSLQ) was used, which was developed to assess university students' motivational orientations and their use of different learning strategies by Pintrich, Smith, Garcia \& McKeachie (1991) and adapted by Buyukozturk, Akgun, Ozkahveci \& Demirel (2004). Some examples of the MSLQ items are shown in Table 2. 
Table 1: Some examples of information literacy self-efficacy scale items

\begin{tabular}{|c|l|}
\hline \multicolumn{2}{|l|}{ I feel confident and competent to } \\
\hline 1. & Define the information I need. \\
\hline 2. & Limit search strategies by subject, language and date. \\
\hline 3. & Decide where and how to find the information I need. \\
\hline 4. & Use Internet search tools (such as search engines, directories, etc.) \\
\hline 5. & Determine the authoritativeness, currentness and reliability of the information sources. \\
\hline 6. & Synthesise newly gathered information with previous information. \\
\hline 7. & $\begin{array}{l}\text { Determine the content and form the parts (introduction, conclusion) of a presentation } \\
\text { (written, oral). }\end{array}$ \\
\hline 8. & Criticise the quality of my information seeking process and its products. \\
\hline
\end{tabular}

Table 2: Some examples of MSLQ items

\begin{tabular}{|c|l|}
\hline 1. & $\begin{array}{l}\text { In a class like this, I prefer course material that really challenges me so I can learn new } \\
\text { things. }\end{array}$ \\
\hline 2. & Getting a good grade in this class is the most satisfying thing for me right now. \\
\hline 3. & When I take a test I think about items on other parts of the test I can't answer. \\
\hline 4. & It is important for me to learn the course material in this class. \\
\hline 5. & I'm confident I can learn the basic concepts taught in this course. \\
\hline 6. & If I don't understand the course material, it is because I didn't try hard enough. \\
\hline 7. & When studying for this course, I often try to explain the material to a classmate or friend. \\
\hline 8. & I usually study in a place where I can concentrate on my course work. \\
\hline 9. & $\begin{array}{l}\text { When I study for this course, I go through the readings and my class notes and try to find } \\
\text { the most important ideas. }\end{array}$ \\
\hline 10. & $\begin{array}{l}\text { When studying for this course, I read my class notes and the course readings over and } \\
\text { over again. }\end{array}$ \\
\hline 11. & $\begin{array}{l}\text { I ask myself questions to make sure I understand the material I have been studying in this } \\
\text { class. }\end{array}$ \\
\hline 12. & I ask the instructor to clarify concepts I don't understand very well. \\
\hline 13. & $\begin{array}{l}\text { I try to understand the material in this class by making connections between the readings } \\
\text { and the concepts from the lectures. }\end{array}$ \\
\hline 14. & $\begin{array}{l}\text { Whenever I read or hear an assertion or conclusion in this class, I think about possible } \\
\text { alternatives. }\end{array}$ \\
\hline 15. & $\begin{array}{l}\text { Even when course materials are dull and uninteresting, I manage to keep working until I } \\
\text { finish. }\end{array}$ \\
\hline
\end{tabular}

The Motivation Scale is composed of 6 factors, "intrinsic goal orientation", "extrinsic goal orientation", "task value", "control belief of learning", "self-efficacy" and "test anxiety" and 31 items. The Learning Strategies Scale is composed of 50 items and 9 factors in total. These factors are "rehearsal strategies", "organising strategies", "elaboration strategies", "critical thinking strategies", "help seeking", "peer learning", "metacognitive strategies", "effort management", and "time and study environment". The 81 items of the MSLQ are scored on a 7 point Likert scale, from 1 (not at all true of me) to 7 (very true of me). Cronbach alpha internal consistency related to sub-scaled factors varies between 0.86 and 0.41 (see Table 3 ).

Demographic data

A form was developed in order to collect data concerning features of e-learners. Questions related to students' gender, age, type of alma mater, Internet and computer use periods, etc. were included in this form. Apart from this, data related to their departments, class level, etc., were collected from the student information system of the university. 
Table 3: Cronbach alpha internal consistency of MSLQ sub-scaled factors

\begin{tabular}{|c|c|c|c|}
\hline \multicolumn{2}{|c|}{ Motivation Scale } & \multicolumn{2}{|c|}{ Learning Strategies Scale } \\
\hline Factors & Cronbach alpha & Factors & Cronbach alpha \\
\hline Intrinsic goal orientation & 0.59 & Rehearsal strategies & 0.62 \\
\hline Extrinsic goal orientation & 0.63 & Organising strategies & 0.61 \\
\hline Task value & 0.80 & Elaboration strategies & 0.74 \\
\hline Control belief of learning & 0.52 & Critical thinking strategies & 0.74 \\
\hline Self-efficacy & 0.86 & Help seeking & 0.49 \\
\hline Test anxiety & 0.69 & Peer learning & 0.46 \\
\hline & & Metacognitive strategies & 0.75 \\
\hline & & Effort management & 0.41 \\
\hline & & Time and study environment & 0.61 \\
\hline
\end{tabular}

\section{Procedure and data analysis}

Data collection tools were transformed into online forms; announced and forwarded to all e-learners asking them to fill in the scales. This announcement was repeated three times at certain intervals. The data collecting tools were administered in Turkish. Records of students who voluntarily filled measurement tools were taken from the database, configured and made ready for analysis.

In the analysis of demographic data, descriptive statistics such as frequency and percentage were used. Arithmetical mean and standard deviation were used in describing data obtained from scales. Regarding the determination of variables predicting students' information literacy self-efficacy, hierarchical regression analysis was applied in the light of the research purposes. Within the scope of hierarchical regression analysis, learning strategies were examined in the first block and motivational factors were examined in the second block.

\section{Results}

With regard to information literacy self-efficacy of e-learners, scores related to subfactors of self-efficacy varied between 5.37 and 5.81 (see Table 4). The information literacy self-efficacy mean of e-learners regarding the scale as a whole was determined to be 5.64. The scores taken from the scale as a whole and those related to scale's subfactors were above scale mid-point and were between usually true (6) and often true (5). The level of e-learners' being information literacy self-efficacy is high, even if it is not too much.

Table 4: Descriptive statistics on information literacy self-efficacy ( $\mathrm{N}=119)$

\begin{tabular}{|l|c|c|}
\hline \multicolumn{1}{|c|}{ Information literacy dimensions } & M & SD \\
\hline General information literacy self-efficacy & 5.64 & 1.06 \\
\hline Defining the need for information & 5.37 & 1.55 \\
\hline Initiating the search strategy & 5.50 & 1.25 \\
\hline Access to information & 5.72 & 1.13 \\
\hline Assessing the information & 5.74 & 1.14 \\
\hline Interpreting the information & 5.79 & 1.20 \\
\hline Communicating information & 5.49 & 1.27 \\
\hline Evaluating the product and the process & 5.81 & 1.30 \\
\hline
\end{tabular}

Learning strategies and motivational factors predicting information literacy selfefficacy of e-learners were handled separately in terms of sub-factors "Defining the 
need for information", "Initiating the search strategy", "Locating and accessing the resources", "Assessing and comprehending the information", "Interpreting, synthesising, and using the information", "Communicating the information" and "Evaluating the product and process" (see Table 5).

Table 5: Summary of the regression analysis results

\begin{tabular}{|c|c|c|c|c|}
\hline Information literacy dimensions & $\begin{array}{l}\text { Learning strategies and } \\
\text { motivation sub factor } \\
\text { (predictors) }\end{array}$ & Beta & $\mathrm{p}$ & $\mathrm{r}^{2}$ \\
\hline \multirow[t]{2}{*}{ Defining the need for information } & Metacognitive strategies & $0.721^{\star *}$ & 0.003 & \multirow[t]{2}{*}{0.337} \\
\hline & Elaboration strategies & $-0.369^{*}$ & 0.021 & \\
\hline \multirow[t]{2}{*}{ Initiating the search strategy } & Metacognitive strategies & $0.730^{* *}$ & 0.000 & \multirow[t]{2}{*}{0.405} \\
\hline & Control belief & $0.197^{*}$ & 0.042 & \\
\hline \multirow[t]{2}{*}{ Access to information } & Metacognitive strategies & $0.548^{\star *}$ & 0.005 & \multirow[t]{2}{*}{0.441} \\
\hline & Control belief & $0.318^{\star *}$ & 0.001 & \\
\hline \multirow[t]{2}{*}{ Assessing information } & Metacognitive strategies & $0.626^{* *}$ & 0.001 & \multirow[t]{2}{*}{0.50} \\
\hline & Effort management & $0.205^{*}$ & 0.026 & \\
\hline Interpreting information & Metacognitive strategies & $0.547^{* *}$ & 0.008 & 0.367 \\
\hline \multirow{4}{*}{ Communicating information } & Metacognitive strategies & $0.659^{* *}$ & 0.001 & \multirow[t]{4}{*}{0.499} \\
\hline & Elaboration strategy & $-0.330^{*}$ & 0.030 & \\
\hline & Critical thinking & $0.278^{*}$ & 0.033 & \\
\hline & Control belief & $0.264^{* *}$ & 0.003 & \\
\hline Evaluating product and process & Metacognitive strategies & $0.586^{\star *}$ & 0.004 & 0.383 \\
\hline \multirow[t]{2}{*}{ General information literacy } & Metacognitive strategies & $0.710^{\star *}$ & 0.000 & \multirow[t]{2}{*}{0.549} \\
\hline & Control belief & $0.251^{\star \star}$ & 0.003 & \\
\hline
\end{tabular}

When variables predicting the factor of defining the need for information were examined, it was seen that metacognitive (Beta $=0.721, p<.01)$ and elaboration (Beta $=-0.369$, $\mathrm{p}<.05)$ strategies were significant predictors. This model explained $34 \%\left(\mathrm{r}^{2}=0.337\right)$ of defining the need for information factor. Use of metacognitive strategies leads to increase in defining the need for information self-efficacy and use of elaboration strategies leads to decrease in same factor.

When variables predicting initiating the search strategy factor were examined, it was detected that metacognitive (Beta $=0.730, \mathrm{p}<.01)$ strategies and at motivation sub-scale, control belief (Beta $=0.197, \mathrm{p}<.05)$ were important factors. This model explained $41 \%\left(\mathrm{r}^{2}\right.$ $=0.405)$ of the variance. This finding can be interpreted as a case where if students use metacognitive strategies and have high control belief, their self-efficacy related to initiating search strategy increases.

Major predictors of access to information self-efficacy of e-learners were metacognitive strategies (Beta $=0.548, \mathrm{p}<.01$ ) at learning strategies scale and control belief (Beta $=0.318$, $\mathrm{p}<.01)$ at motivation sub-scale. This model explained $44 \%\left(\mathrm{r}^{2}=0.441\right)$ of the variance. This indicates that students who can use metacognitive strategies and have high control belief in learning, can access information more easily.

Metacognitive (Beta $=.626, \mathrm{p}<.01)$ and effort management $(B e t a=.205, \mathrm{p}<.05)$ strategies were detected to be major predictors, when variables predicting students' assessing information self-efficacy were examined. This model explained $50 \%\left(\mathrm{r}^{2}=0.50\right)$ of the variance. Student's use of metacognitive strategies and ability to manage effort for learning increase their assessing information self-efficacy. 
There was only one factor predicting interpreting information self-efficacy, which was the use of metacognitive (Beta $=0.547, \mathrm{p}<.01)$ strategies. This model explained $37 \%\left(\mathrm{r}^{2}=\right.$ 0.367) of the variance. This finding shows that the interpreting information self-efficacy of e-learners capable of using metacognitive strategies increases.

When variables predicting students' communicating the information self-efficacy were examined, it was found that at learning strategies scale, metacognitive (Beta $=0.659$, $\mathrm{p}<.01$ ), elaboration (Beta $=-0.330, \mathrm{p}<.05)$ and critical thinking (Beta $=0.278, \mathrm{p}<.05$ ) strategies; at motivation scale, control belief $(B e t a=0.264, p<.01)$ were major predictors. This model explained $50 \%\left(\mathrm{r}^{2}=0.499\right)$ of the variance. This indicates that students' communicating the information self-efficacy increases when they use metacognitive and critical thinking strategies and have control over learning; however, their communicating the information sharing self-efficacy decreases where they use elaboration strategies. As the same time, only the metacognitive (Beta $=.586, \mathrm{p}<.01$ ) strategies factor predicted evaluating product and process self-efficacy. This model explained $38 \%\left(\mathrm{r}^{2}=0.383\right)$ of the variance. Students who use the metacognitive strategies more have increased their evaluating product and process self efficacy.

When factors predicting general information literacy self-efficacy that covered the overall information literacy aspects mentioned above were examined, as expected, it was found out that metacognitive $(B e t a=0.710, p<.01)$ strategies factor was the major predictor, as well as the control belief (Beta $=0.251, \mathrm{p}<.01)$ factor at motivation scale. This model explained $55 \%\left(\mathrm{r}^{2}=0.549\right)$ of the variance. In short, information literacy self-efficacy of students increases when they frequently use metacognitive strategies and highly believe that they have control over learning processes.

\section{Discussion}

Information literacy is directly related to the concepts of lifelong learning and independent learning. Therefore, information literacy is also an important concept for e-learners who prefer independent learning. At the same time, motivation of e-learners throughout the process and their use of appropriate learning strategies directly affect their success. Within the scope of the study, how these concepts, which are so vital for e-learners, interact with each other was investigated through identification of learning strategies and motivational factors predicting information literacy.

In this context, the findings indicated that the most important factor, predicting the all sub-dimensions of the e-learners' information literacy self-efficacy was the use of metacognitive strategies. Metacognitive strategies are especially important in the planning, organising and self-evaluation of information construction process by self regulated students. Those students capable of using metacognitive strategies are aware of and have control over their own learning process (Pintrich et al., 1991). Use of metacognitive learning strategies increases both information literacy self-efficacy perception and self-efficacy belief, thus enabling students to achieve more success, as also stated by Pintrich and De Groot (1990). Researchers have stressed that especially students of e-learning environments should have higher order skills and these skills have critical importance for distance education (Bates, 1996; Jonassen, 2001). On the other hand, White (1997) stressed that students should use metacognitive skills more frequently in order to have information on their own learning process and to be able to manage this process. Serrano and Alford (2000) stated that e-learning environment should be designed in such a way which enables students improve their higher order 
critical thinking and information literacy skills (Strother, 2002). Moreover, studies by Hadwin and Winne (2001), and Azevedo and Cromley (2004) indicated that students learnt less and did not use cognitive and metacognitive strategies effectively in learning processes in e-learning environments (Kramarski \& Gutman, 2006). The reason for students' failure in this process might be their use of inappropriate cognitive and metacognitive strategies. Therefore, use of metacognitive strategies shall enable elearners to define their information needs, develop proper searching strategies, access to information, assess information accessed, interpret information, evaluate the product and the process through interpreting information which are dimensions of information self efficacy, and at the same time, lead to an improvement in their performance.

Apart from metacognitive strategies, various learning strategies predicted the subfactors of information literacy. Effort management within the learning strategies was a factor predicting assessing information self-efficacy of students. Effort monitoring is the skill of controlling and managing the effort and concentration of students so that they are able to fulfill even a boring and distracting task (Miltiadou \& Savenye, 2003). In other words, it is students sustaining their concentration and effort in fulfilling an assigned task, continuing to use appropriate learning strategies, and persisting at difficult tasks. Students' ability to assess information at different levels of complexity is of vital importance for configuring the information. Especially for e-learners, who are in general alone in fulfilling complex tasks in learning processes, assessing information and controlling the accuracy of the information, is very important but difficult. However, those students who are able to manage their efforts related to learning and task do not have any difficulty in assessing information. Eccles (1983) and Pintrich $(1988,1989)$, in their studies, pointed out that students who are able to regulate learning goals and have high task value, more often learn by using metacognitive strategies and are able to manage their effort in an effective manner. From this point of view, it can be proposed that metacognitive strategies play a significant role in students' managing their effort properly. At the same time, studies have displayed a positive relation between effort management and performance (Liu, Chuang \& Huang, 2008).

On the other hand, critical thinking predicted communicating information self-efficacy of students. Both critical thinking and effort management were among the factors that enable students to manage the process. Critical thinking refers to a student's ability to adapt previously acquired information, during problem solving, decision making and critical evaluation processes, to new situations (Pintrich et al., 1991). Individual who have critical thinking skills can make deductions, synthesise and integrate information, and more importantly, can make evaluations on the quality of their own thinking processes (Senate Committee on Curricular Affairs, 2004). Hence, individuals who are able to filter information at different settings use existing or obtained information correctly; in brief, those who know how to use information and believe that they are managing the process properly are better able to share their new information.

Elaboration strategy was a factor that leads to decrease in defining needs for information and communicating information self-efficacy of students. Elaboration strategy requires students to take notes, compare information they read and acquire with course notes, make summaries, make their own sentences, and find their own examples for real life events and problems (Talbot, 1997). Askell-Williams, Lawson and Murray-Harvey (2007) stated that elaboration strategy plays an especially important role in acquiring information. As the use of elaboration strategy helps students to integrate new 
information with previous information, and to code information into long term memory, students can more easily notice information that they might need. Besides, students using this strategy can more easily share their information, as they are able to use note taking strategies and to comment and summarise. Contrary to these explanations, in this study, one reason why elaboration strategy negatively affects students' defining needs for information and communicating information self-efficacy may stemm from a lack of digital sources and an environment that enables them to use and improve elaboration strategy.

On the other hand, control belief was the single motivational factor predicting general information literacy self-efficacy of e-learners. Increase in control belief leads to improvement in students' ability to develop searching strategies, access to information and communicating information self-efficacy. Pintrich et al. (1991) indicated that control belief was a factor that affects student's motivation related to task in the learning process. Control belief is perception regarding the existence of required skills, resources and opportunities. Being successful, in a sense, requires evaluating these sources. Students suppose that they will be faced with fewer problems when they believe that they possess all types of sources and opportunities they might need, and this makes them feel that they have more control over their behaviours. Therefore, students thinking that they have control over their behavior can develop self-styled searching strategies, access to information needed and communicate easily the information obtained. With reference to e-learners, these students being more independent in their learning processes and the provision of necessary sources and opportunities to these students can help improve their control beliefs on learning. These students have control over their learning and their perceptions and belief regarding this, thereby increasing both their motivation and information literacy selfefficacy. Student who have control over their own learning can also control and sustain their efforts in the learning process (Miltiadou \& Savenye, 2003).

\section{Conclusion}

Suggestions about improving information literacy self efficacy and motivational and learning strategies of e-learners are summarised below:

- For ensuring and making widespread use of metacognitive strategies, students should be provided with environments where they are able to do planning, monitoring and regulating. Through assigning them with different tasks, these strategies should be further developed. It would be beneficial to use different interactive media such as wikis and blogs that are developed to ensure the use of metacognitive strategies by students. While fulfilling tasks using these media, the instructor's supervision and guidance are necessary, for example as in the study conducted by McGill, Nicol, Littlejohn, Grierson, Juster and Ion (2005).

- Learning how to manage their efforts to increase their beliefs related to assess information in e-learning environments should be a primary goal for students and instructors.

- Assigning complex tasks which are directed towards improving students' critical thinking skills should bring benefits. As Oliver (2001) suggests, constructivist learning environments should be designed, such as inquiry based learning, case based learning, project based learning, problem based learning and different approaches should be followed in designing e-learning environments. 
- Activities whereby students can make summaries and take notes should be designed in order to encourage e-learners to use elaboration strategy. Additionally, tools and interaction instruments should be provided to enable students to express themselves and interact with other students, to share their information and put forward their own examples. To enable this goal, media such as chat, forum and interactive whiteboard, and tools such as wikis and blogs, should be especially beneficial, as they may be used to not only increase learners' information sharing, but also improve their interpreting and higher thinking skills.

- Providing for the development of self- control to improve performance and information literacy self efficacy of e-learners minimises the problems that elearners may face and also guides them to take more responsibility.

- Direct training should be provided to enhance motivational and learning strategies which improve information literacy.

In this study, learning strategies and motivational factors predicting information literacy self-efficacy of e-learners were investigated. Students' use of certain motivational and learning strategies is attested by the study conducted to be crucial in the increase of their information literacy self-efficacy levels. According to these results, and as indicated by Bruce (2004), successful information literacy programs do not focus only on teaching information skills, but also on designing learning experiences that necessitate the use of information skills. Even if lessons directly related to information literacy are not included in the curriculum of e-learning programs, ensuring students use certain learning and motivational strategies during lectures and learning activities will affect their information literacy levels positively. For this reason, further studies should include interviews with instructors of e-courses in order to obtain sound evidence towards increasing information literacy level of students in the Computer Technologies and Programming, and the Business Administration departments, and to specify things that are already done or are to be done. In this way, information obtained from instructors will help in making necessary updates and arrangements while designing e-lesson content. Furthermore, considering the dimensions of information literacy, qualitative data concerning the problems faced by students during learning processes and potential solutions can be obtained and analysed. Besides, the effect of information literacy self-efficacy on educational success and satisfaction can be analysed also.

Another factor which is important for e-learners is computer literacy. Factors affecting digital information literacy and computer literacy can be identified and the relationships of these factors to information literacy and its success can be discussed. Future studies may also reveal the factors to be focused on for improving the quality of e-learning processes. During the process of e-learning, the parts of learning management systems which facilitate the learners' development of information literacy through motivational and learning strategies should be examined.

\section{References}

ALA (American Library Association) (1989). Presidential Committee on Information Literacy. Final Report. Chicago: American Library Association. [viewed 24 Aug 2008] http: / / www.ala.org/ala/mgrps / divs/acrl/publications/whitepapers/ presidential.cfm

ALA (American Library Association) (2000). Information Literacy Competency Standards for Higher Education. [viewed 24 Aug 2008] http:/ / www.ala.org/ala/mgrps/divs/acrl/standards/standards.pdf 
American Library Association and AECT (1998). Information Power: Guidelines for School library media programs. Chicago: ALA and AECT. [verified 24 Mar 2010; $3.2 \mathrm{MB}$ ] http:/ / www.eric.ed.gov:80/ERICWebPortal/custom/portlets/recordDetails/detailmini.jsp?_nfpb=true \&_\&ERICExtSearch_SearchValue_0=ED315028\&ERICExtSearch_SearchType_0=no\&accno=ED315028

Askell-Williams, H., Lawson, M. \& Murray-Harvey, R. (2007). What happens in my university classes that helps me to learn? Teacher education students' instructional metacognitive knowledge. International Journal for the Scholarship of Teaching and Learning, 1(1). [viewed 12 Sep 2008, verified 24 Mar 2010] http: / / academics.georgiasouthern.edu/ijsotl/v1n1/ askell_ williams/IJ_Askell-Williams_et_al.pdf

Azevedo, R. (2005). Using hypermedia as a metacognitive tool for enhancing student learning? The role of self-regulated learning. Educational Psychologist, 40(4), 199-209.

Azevedo, R. \& Cromley J. G. (2004). Does training of self-regulated learning facilitate student's learning with hypermedia? Journal of Educational Psychology, 96, 523-535.

Barnard, L., Lan, W. Y., To, Y. M., Paton, W. O. \& Lai, S. (2009). Measuring self-regulation in online and blended learning environments. The Internet and Higher Education, 12, 1-6.

Bates, A. W. (1996). The impact of technological change on open and distance learning. Keynote address at Open Learning: Your Future Depends on It. Queensland Open Learning Network, Brisbane, Queensland, Australia. Also published 1997 in Distance Education, 18(1), 93-109.

Bodi, S. (1990). Through a glass darkly: Critical thinking and bibliographic instruction. Catholic Library World, 61(6), 252-256.

Breivik, P. S. \& Gee, E. G. (1989). Information literacy: Revolution in the library. New York: Macmillan.

Bruce, C. S. (1997). Seven faces of information literacy. AULSIB Press, Adelaide.

Bruce, C. S. (2004). Information literacy as a catalyst for educational change. A background paper. In P. A. Danaher (Ed.), Proceedings of Lifelong Learning: Whose responsibility and what is your contribution? 3rd International Lifelong Learning Conference, pp. 8-19, Yeppoon, Queensland. [verified 24 Mar 2010] http:/ / eprints.qut.edu.au/4977/1/4977_1.pdf

Buyukozturk, S., Akgun, O. E., Ozkahveci, O. \& Demirel, F. (2004). The validity and reliability study of the Turkish version of the Motivated Strategies for Learning Questionnaire. Educational Sciences: Theory \& Practice, 4(2), 207-239.

Candy, P., Crebert, G. \& O'Leary, J. (1994). Developing lifelong learners through undergraduate education. Commissioned Report No. 28, Canberra, National Board of Employment, Education and Training. [verified 24 Mar 2010] http://www.dest.gov.au/sectors/training_skills/publicat ions_resources/profiles/nbeet/hec/developing_lifelong_learners_through_undergraduate.htm

Chen, N. S. \& Lin, K. M. (2002). Factors affecting e-learning for achievement. IEEE International Conference on Advanced Learning Technologies, September 9-12. [verified 24 Mar 2010] http: / / lttf.ieee.org/icalt2002/proceedings/t502_icalt148_End.pdf

Corrall, S. (2008). Information literacy strategy development in higher education: An exploratory study. International Journal of Information Management, 28, 26-37.

Donaldson, K. A. (2000). Library research success: Designing an online tutorial to teach information literacy skills to first-year students. The Internet and Higher Education, 2(4), 237-251.

Dabbagh, N. \& Kitsantas, A. (2005). Using web-based pedagogical tools as scaffolds for selfregulated learning. Instructional Science, 33, 513-540.

Doyle, C. (1992). Outcome measures for information literacy within the national education goals of 1990. Final Report to the National Forum on Information Literacy. Summary of Findings. ED 351033. [verified 24 Mar 2010] http:/ / www.eric.ed.gov:80/ERICDocs/data/ericdocs2sql/ content_storage_01/0000019b/80/13/2c/6e.pdf

Eccles, J. S. (1983). Expectancies, values and academic behaviors. In J. T. Spence (Ed.), Achievement and achievement motives (pp. 75-146). San Francisco: Freeman. 
Eisenberg, M. B. \& Berkowitz, R. E. (1990). Information problem solving: The Big Six approach to library and information skills instruction. Norwood, NJ, Ablex.

Feast, V. (2003). Integration of information literacy skills into business courses. Reference Services Review, 31(1), 81-95.

Garcia, T. \& Pintrich, P. R. (1996). Assessing students' motivation and learning strategies in the classroom context: The motivated strategies for learning questionnaire. In M. Brenbaum \& F. J. R. C. Dochy (Eds), Alternatives in assessment of achievements, learning processes and prior knowledge. Kluwer Academic Publishers. Boston/Dordrecht/London.

Gerbic, P. (2004). What about flexible learning and ICT? - A review of technology based flexible learning in tertiary education. Third Pan-Commonwealth Forum Conference, 4-8 July 2004, New Zealand. [viewed 24 Sep 2008, verified 25 Mar 2010] http: / / www.col.org/pcf3/Papers/PDFs/Gerbic_Philippa.pdf

Hadwin A. \& Winne P. (2001) CoNoteS2: A software tool for promoting self-regulation. Educational Research and Evaluation, 7, 313-334.

Hara, N., Bonk, C. J. \& Angeli, C. (2000). Content analysis of online discussion in an applied educational psychology course. Instructional Science, 28(2), 115-152.

Harasim, L. M. (1990). Online education: An environment for collaboration and intellectual amplification. In L. M. Harasim (Ed.), Online education: Perspectives on a new environment (pp. 39-64). New York: Praeger.

Hawes, D. K. (1994). Information literacy and the business schools. Journal of Education for Business, 70(1), 54-61.

Higgins, B.A. (2000). An analysis of the effects of integrated instruction of metacognitive and study skills upon the self-efficacy and achivement of male and female students. Master's Research Project, Miami University, Ohio. ERIC\# ED447152. [verified 25 Mar 2010; 1.3 MB] http:/ / www.eric.ed. gov:80/ERICWebPortal/custom/portlets/recordDetails / detailmini.jsp?_nfpb=true\&_\&ERICExtSearch_ SearchValue_0=ED447152\&ERICExtSearch_SearchType_0=no\&accno=ED447152

Hodges, C. B. (2005). Self-regulation in web-based courses: A review and the need for research. Quarterly Review of Distance Education, 6, 375-383.

Jonassen, D. (2001). E-learning to solve problems. Keynote address at EDMEDIA 2001: World Conference on Educational Multimedia, Hypermedia, and Telecommunications. June, Tampere, Finland.

Johnson, D. W., Bartholomew, K. W. \& Miller, D. (2006). Improving computer literacy of business management majors: A case study. Journal of Information Technology Education, 5.

Kelly, O., Coburn, D., Hegarty, B., Jeffrey, L. \& Penman, M. (2009). Don't dilly dally on the way: Driving towards digital information literacy capability. In Same places, different spaces. Proceedings ascilite Auckland 2009.

http: / / www.ascilite.org.au/conferences/ auckland09/procs/kelly-o.pdf

Kramarski, B. \& Gutman, M. (2006). How can self-regulated learning be supported in mathematical E-learning environments? Journal of Computer Assisted Learning, 22(1), 24-33.

Kramarski, B. \& Mizrachi, N. (2006). Online discussion and self-regulated learning: Effects of instructional methods on mathematical literacy. The Journal of Educational Research, 99(4), 218230.

Kurbanoglu, S. S., Akkoyunlu, B. \& Umay, A. (2006). Developing the information literacy selfefficacy scale. Journal of Documentation, 62(6), 730-743.

Lance, K. \& Potter, S. (1995). Integrating library instruction into course modules. In C. J. Jacob (Ed), The Seventh Off-campus Library Services Conference Proceedings. Mount Pleasant, Michigan: Central Michigan University. 
Liu, H., Chuang, H. \& Huang, J. (2008). The correlation among web-based learners' self-efficacy, learning strategies and outcomes. In K. McFerrin et al. (Eds.), Proceedings of Society for Information Technology and Teacher Education International Conference 2008 (pp. 3030-3034). Chesapeake, VA: AACE.

Lyman, B. (1999). Internet-based learning. What's in it for the adult learner? In Internet based learning: An introduction and framework for higher education and business. Virginia: Stylus Publishing.

Maybee, C. (2006). Undergraduate perceptions of information use: The basis for creating usercentered student information literacy instruction. The Journal of Academic Librarianship, 32(1), 79-85.

McGill, L., Nicol, D., Littlejohn, A., Grierson, H., Juster, N. \& Ion, W. J. (2005). Creating an information-rich learning environment to enhance design student learning: Challenges and approaches. British Journal of Educational Technology, 36(4), 629-642.

McGuiness, C. (2006). What faculty think - exploring the barriers to information literacy development in undergraduate education. The Journal of Academic Librarianship, 32(6), 573-82.

Miltiadou, M. \& Savenye, W. C. (2003). Applying social cognitive constructs of motivation to enhance student success in online distance education. AACE Journal, 11(1). [viewed 26 Oct 2008, verified 25 Mar 2010] http:/ / www.aace.org/pubs/etr/issue4/ miltiadou2.pdf

Moore, M. G. \& Kearsley, G. (1996). Distance education: A systems view. Belmont, California: Wadsworth Publishing Company.

Nevgi, A. (2001). Motivational strategies of students in virtual university. Third International Inter-disciplinary Evidence Based Policies and Indicator-Based Systems Conference. [viewed 24 May 2008, verified 25 Mar 2010] http:/ / www.cemcentre.org/Documents/CEM\%20Extra/EBE/ EBE2001/P203-219\%20Anne\%20Nevgi.pdf

Oliver, R. (2001). Developing e-learning environments that support knowledge construction in higher education. 2nd International We-B Conference. [viewed 24 Sep 2008, verified 25 Mar 2010] http:/ / www.business.ecu.edu.au/schools/mis/media/pdf/0043.pdf

Pinto, M. (2010). Design of the IL-HUMASS survey on information literacy in higher education: A self-assessment approach. Journal of Information Science, 36(1), 86-103.

Pintrich, P. R. (1988). A process-oriented view of student motivation and cognition. In J. S. Stark \& L. A. Mets (Eds), Improving teaching and learning through research. New Directions for Institutional Research, no. 57. San Francisco: Jossey-Bass.

Pintrich, P. R. (1989). The dynamic interplay of student motivation and cognition in the college classroom. In C. Ames \& M. Maehr (Eds.), Advances in motivation and achievement: Motivationenhancing environments (Vol. 6, pp. 117-160). Greenwich, CT: JAI Press.

Pintrich, P. R. \& De Groot, E.V. (1990). Motivational and self-regulated learning components of classroom academic performance. Journal of Educational Psychology, 82(1), 33-40.

Pintrich, P. R., Smith, D. A. F., Garcia, T. \& McKeachie, W. J. (1991). A manual for the use of the Motivated Strategies for Learning. Michigan: The University of Michigan. ERIC database number: ED338122. http: / / www.eric.ed.gov:80/ERICDocs/ data/ericdocs2sql/ content_ storage_01/0000019b/80/23/3c/44.pdf

Pintrich, P. R., Smith, D. A. F., Garcia, T. \& McKeachie, W. J. (1993). Reliability and predictive validity of the motivated strategies for learning questionnaire (MSLQ). Educational and Psychological Measurement, 53(3), 801-814.

Pokay, P. \& Blumenfeld, P. C. (1990). Predicting achievement early and late in the semester: the role of motivation and use of learning strategies. Journal of Educational Psychology, 82(1), 41-50.

Rovai, A. P. (2003). In search of higher persistence rates in distance education online programs. The Internet and Higher Education, 6, 1-16. 
Rowntree, D. (1995). Teaching and learning online: A correspondence education for the 21st century? British Journal of Educational Technology, 26(3), 205-215.

Sacchanand, C. (2002). Information literacy instruction to distance students in higher education: Librarians' key role. 68th IFLA Council and General Conference, 18-24 August. http:/ / www.er ic.ed.gov:80/ERICDocs/ data/ ericdocs2sql/content_storage_01/0000019b/80/1a/bf / cf.pdf

Senate Committee on Curricular Affairs (2004). Guide to curricular procedures. [viewed 22 Sep 2008, verified 25 Mar 2010] http:/ / www.psu.edu/ufs/guide/glossary.html

Serrano, C. \& Alford, R. L. (2000). Virtual languages: An innovative approach to teaching EFL/ESL English as a foreign language on the World Wide Web. In L. Lloyd (Ed.), Teaching with technology: Rethinking tradition. p. 195-205. Medford, NJ: Information Today, Inc.

Sharma, S., Dick, G., Chin, W. \& Land, L. P. W. (2007). Self-regulated learning and e-learning. In H. Österle, J. Schelp \& R. Winter (Eds), Proceedings of the Fifteenth European Conference on Information Systems, p.383-394. University of St. Gallen, St. Gallen.

Small, R. V., Zakaria, N. \& El-Figuigui, H. (2004). Motivational aspects of information literacy skills instruction in community college libraries. College $\mathcal{E}$ Research Libraries, 65(2), 96-121.

Stipek, D. (1998). Motivation to learn: From theory to practice. Massachusetts: A Viacom Company.

Strother, J. (2002). An assessment of the effectiveness of e-learning in corporate training programs. International Review of Research in Open and Distance Learning, 3(1). http: / / www.irrodl.org/index.php/irrodl/article/viewFile/83/161

Talbot, G. L. (1997). Helping teachers and students talk about learning strategies for teacher-made tests and assignments. ERIC Document Reproduction Service No. ED 411203. http: / / www.eric.ed. gov:80/ERICDocs / data / ericdocs2sql/ content_storage_01/0000019b/80/14/f2 /ff.pdf

Thomas, G. M. (1995). Education - past, present, future. In D. R. Walling (Ed.), At the threshold of the millennium. Bloomington, Indiana: Phi Delta Kappa.

Tsai, M. J. (2009). The model of strategic e-learning: Understanding and evaluating student elearning from metacognitive perspectives. Educational Technology E Society, 12(1), 34-48. http: / / www.ifets.info/journals/12_1/4.pdf

United States Distance Learning Association (2006). Distance education: Definition and glossary of terms (2nd ed.). Information Age Publishing. [viewed 24 Oct 2008, verified 26 Mar 2010)] http:/ / www.usdla.org/Glossary_Distance.pdf

Weinstein, C. E. \& Mayer, R. E. (1986). The teaching of learning strategies. In M. Wittrock (Ed.), Handbook of research on teaching. New York: Macmillan.

Whipp, J. L. \& Chiarelli, S. (2004). Self-regulation in a web-based course: A case study. Educational Technology Research and Development, 52(4), 5-22.

White, C. J. (1997). Effects of mode of study on foreign language learning. Distance Education, 18(1), 178-196.

Zimmerman, B.J. \& Martinez-Pons, M. (1990). Student differences in self-regulated learning: Relating grade, sex and giftedness to self-efficacy and strategy-use. Journal of Educational Psychology, 82(1), 51-59.

Dr Ebru Kilic-Cakmak, Assistant Professor, Department of Computer Education and Instructional Technologies, Gazi Education Faculty, Gazi University

L Block, No: 304, 06500, Besevler, Ankara, Turkey

Email: ekilic@gazi.edu.tr, ebrukilic@gmail.com Web: http: / /w3.gazi.edu.tr/web/ ekilic 